Available at http://jurnal.utu.ac.id/JNS/article/view/2252

\title{
The Association Between Fishermen Status and Food Security of Fishermen Families in The District West Aceh
}

\author{
${ }^{1}$ Wardah Iskandar, ${ }^{2}$ Rizki Maulidya, ${ }^{3}$ Ishalyadi Ishalyadi \\ ${ }^{1}$ Public Health Faculty, Teuku Umar University, Meulaboh, Indonesia, wardahiskandar@utu.ac.id \\ ${ }^{1}$ Public Health Faculty, Teuku Umar University, Meulaboh, Indonesia, rizkimaulidya@utu.ac.id \\ ${ }^{1}$ Public Health Faculty, Teuku Umar University, Meulaboh, Indonesia, ishalyadi@utu.ac.id \\ Coresponding author : Wardah Iskandar, e-mail : wardahiskandar@utu.ac.id
}

\begin{abstract}
Fishermen are one of the livelihoods of the people in Indonesia, they depend on sea products, referring to development priorities in improving the quality of people and society that produce superior Indonesian humans, of course, also determined by adequate nutrition and nutritional adequacy is largely determined by food security in a family. The purpose of this study to determine the association between status of fishermen with food security in fishing families in the district West Aceh. This research method uses a cross-sectional study. The sample in this study amounted to 122 fishing families. Data collection was carried out by means of direct interviews covering the status of fishermen and food security, data analysis included univariate analysis, bivariate with independent sample t-test, and multivariate regression analysis. The results of research on 122 fishing families known that $56.25 \%$ of fishermen families who have capital have good food security, while $90.48 \%$ of laboring fishing families have poor food security. Bivariate analysis shows the variable of food security, with the status of fishermen having a value of $\mathrm{P}<0.05$ which can be assumed that there is a significant difference between food security and the status of fishermen.
\end{abstract}

How to cite this article: Iskandar, W., Maulidya, R., Ishalyadi, I. (2020). The Association Between Fishermen Status and Food Security of Fishermen Families in The District West Aceh. JNS : Journal of Nutrition Science, $1(1), 19-21$.

\section{Introduction}

Many Indonesian people depend on marine products, in 2011 fishermen in Indonesia reached 2.2 million and $95 \%$ of them were traditional fishermen (Kementrian Kelautan dan Perikanan 2012).

The income earned by fishermen generally depends on the catch of the fish so that there is no fixed income they get. When viewed from the fishermen's food needs, only fish which are their main source of protein are obtained free of catch. However, if the catch is small the fishermen are forced to have to sell all their fish and also processed for resale so that there is no excess for their family to consume, this is done to meet other basic needs (Darmawaty, 2006).

Fishermen are divided into 2 groups, namely labor fishermen and fishermen who have capital. Labor fishermen are fishermen who work with other people's fishing gear, while capital fishermen are fishermen who have fishing gear operated by themselves or others. (Subri, 2005).

The level of income greatly determines the status of household food security, and will affect food supply patterns. A food-resistant household is reflected in its ability to meet adequate and nutritious food needs for the whole family. Food availability in the family will affect the intake of nutrients for each family member (Suyanto, 2005).

\section{Method}

This research is a quantitative type with a cross-sectional research design to determine the association between the status of fishermen with food security, the status of fishermen and food security on the research object observed and measured at the same time.

The sample in this study amounted to 122 fishing families in Aceh Barat District. The measurement of food security combines two 
indicators, namely the level of food expenditure and the average energy consumption of the family, which then determines food security is categorized into two, namely food security both if the food-resistant family and the food-vulnerable family, for families with food security is not good if the family lacks food and food insecure families. for the status of fishermen can be divided into two, namely the owners of capital and labor. The analysis used in this study is bivariate analysis (chi square).

\section{Results}

The results of the study using bivariate analysis aimed to see the relationship between independent and dependent variables. Where the independent variable is food security and the dependent is the status of fishermen,

Tabel 1. The association between fisherman status and food security

\begin{tabular}{ccccccc}
\hline Variable & $\begin{array}{c}\text { Capital } \\
\text { owners } \\
\mathbf{n = 4 9}\end{array}$ & $\begin{array}{c}\text { Laborers } \\
\mathbf{n = 7 3})\end{array}$ & $\begin{array}{c}\text { Total } \\
(\mathbf{n = 1 2 2})\end{array}$ & $\mathbf{P}$ & OR & 95\% CI \\
\hline $\begin{array}{c}\text { Food security } \\
\quad \text { Good }\end{array}$ & $45(56,25)$ & $35(43,75)$ & $80(100)$ & $0,000^{* *}$ & 12,21 & $3,79-50,55$ \\
poorly & $4(9,52)$ & $38(90,48)$ & $42(100)$ & & & \\
\hline
\end{tabular}

From the results of research on the families of fishing capital owners and families of labor fishermen it is known that $56.25 \%$ of the fishing families of capital owners have good food security while $90.48 \%$ of labor fishing families have poor food security. Bivariate analysis shows the variable of food security, with the status of fishermen having a value of Pvalue $<0.05$ which can be assumed that there is a significant difference between food security and the status of fishermen.

\section{Discussion}

Sub From the results of the study it can be seen that the family of fishermen who have capital have good food security where out of a total of 122 fishing families there are 80 families of fishermen who have good food security including $56.25 \%$ are families of fishermen who have capital. When viewed from the food security of fishermen family families out of a total of 122 fishing families, 42 fishing families have poor food security and among them $90.48 \%$ percent come from labor fishing families.

It can be interpreted that fishermen who have capital with better income than labor fishermen have better food security than families of labor fishermen and this is reinforced by the results of a bivariate test where the $\mathrm{P}$ value $<0.05$ is where there is a significant difference between food security and fisherman status. The OR value of 12.21 which can be interpreted that the family of fishermen who have capital is 13 times better food security compared to the families of fishing fishermen.
Food availability in the family will affect the intake of nutrients for each family member. Food security and good nutritional status are basic requirements for the formation of quality human resources. Households with good food security and nutritional status will produce children with optimal physical quality and intelligence, and if supported by adequate environmental factors will be able to achieve achievements in the educational process in their path. (Suyanto, 2005).

Similar study was conducted by Sujai (2011), that study took place in Yogyakarta district on. The result was among 42 children, there was an association between household food security and academic achievement especially for mathematics (59.2\%). On les adequate household food security, there were 29 students who didn't get sufficient mark for mathematics $(40.8 \%)$. This result was statistically associated between these two aspects ( $\mathrm{p}=0.045$, OR 2.340). this study found that children from less adequate household food security have risk 2.34 higher to fail on mathematics than others.

\section{Conclusion}

There is a significant association between the status of fishermen with food security in the families of fishermen in Aceh Barat District

\section{Acknowledgement}

The researcher would like to thank the Head of the All person who helped during the data collection process in this study.

Author Contribution and Competing Interest 
During the process of collecting, processing and analyzing data to the interpretation of all writers, they contributed and ensured that there were no conflicts of interest related to this text.

\section{Publisher's Note}

The researcher would like to thank the Head of the All person who helped during the data collection process in this study.

\section{References}

BAPPEDA Aceh Barat, 2015. Profil Aceh Barat 2015. Aceh Barat.

Damayanti, Didit Muhilal. 2006. Gizi Seimbang Untuk Anak Usia Sekolah Dasar. Jakarta: EGC.
Direktorat Jenderal Perikanan Tangkap DKP, 2006. Kebijakan Pengelolaan Sumberdaya Ikan Dalam Rangka Pengelolaan Perikanan Yang Bertanggung Jawab Sebagai Upaya Penanggulangan Konflik Nelayan.

Depkes, 2009. Sistem Kesehatan Nasional. Jakarta

Dinkes. 2015. Rencana Strategis Kementerian Kesehatan Tahun 2015-2019. Jakarta: Kementerian Kesehatan RI; 2015

Ditjen P2HP KKP, 2015. Profil P2HP KKP Aceh Barat Tahun 2015. Aceh Barat

Subri, M. 2005. Ekonomi Kelautan. Jakarta: Raja Grafindo Persada.

Suyanto, 2005. Konsep Dasar Anak Usia Dini : Jakarta : Departemen. Pendidikan Nasional.

Sujai, A. 2011. Hubungan Ketahanan Pangan Rumah Tangga dan Status Gizi anak Keluarga dengan Prestasi Belajar Siswa SD di Kota Yogyakarta [Tesis]. Yogyakarta: Program Pscasarjana Kedokteran UGM. 